\title{
The Principally of the Obligations of Legal Consultant's as a Capital Market Supporting Profession in the Preparation of Independent Legal Due Diligence
}

\author{
Budi Endarto $^{1} \quad$ Slamet Suhartono $^{2} \quad$ Sri Setyadji $^{2}$ \\ 1. Doctorate of Law Candidate at Law Faculty of 17 Agustus 1945 University of Surabaya, Surabaya, Indonesia \\ 2.Lecturer of Faculty of Law, 17 Agustus 1945 University of Surabaya, Surabaya, Indonesia
}

\begin{abstract}
The obligation of a legal consultant as a capital market supporting profession regulated in article 67 of Law Number 8 of 1995 on the Capital Market is "to provide an independent opinion or assessment". When alignment with the Advocate Law, the formulation of the article contradicts the pricinple of an advocate in providing legal services as stipulated in Article 1 point 2 in Law Number 18 of 2003 on Advocates, that "an advocate takes legal action for the client's legal interest". Thus, this contradiction serves as the background of the following problem formulations proposed: (1) The principally of the obligations of legal consultant's as a capital market supporting profession in the preparation of independent legal due diligence; (2) Legal due diligence as an independent opinion of a legal consultant to provide legal protection for investors. The two problem formulations were analyzed using normative legal research method, a research method to identify legal concepts and principles related to legal regulation in the capital market. After conducting a juridical, theoretical, and philosophical analysis, the findings obtained were: (1) The principally of the obligations of legal consultant's as a capital market supporting profession in the preparation of independent legal due diligence is manifested through an independent attitude, meaning that it is not controlled, not affiliated, no conflict of interest, and no partial element with service users. (2) Since the legal relationship between the legal consultant and service users is bound by an agreement, the parties have built their respective internal legal protections. Although this legal relationship can be categorized as an internal legal protection effort based on the privity of contract, it must also pay attention to the legislation, customs, and propriety that develop (heteronomous elements).
\end{abstract}

Keywords: Legal Due Diligence, Independent, Internal Legal Protection

DOI: $10.7176 / \mathrm{JLPG} / 101-02$

Publication date:September $30^{\text {th }} 2020$

\section{Introduction}

The capital market is indispensable for the development of a country's economy. It is because the capital market basically carries out two important functions in driving the economy of a country: the economic function and the financial function. ${ }^{1}$ Philosophically, the capital market in Indonesia has a very strategic role in national development as a source of financing for the business world and a platform for investment. This means that the capital market aims to support the implementation of national development in order to increase equitable growth and national economic stability towards improving the welfare of the community. From an economic aspect, the objective of developing a capital market in a country is to raise funds, where the capital market has an important role as a source of financing for the medium and small business world, to build the business world, and as a platform for investment. ${ }^{2}$ From the socio-political aspect, the capital market is a means of democratizing company ownership and expanding public participation in owning shares as an effort to distribute income. ${ }^{3}$

The main principle in the capital market is the disclosure which serves as the spirit of the capital market itself. The definition of the disclosure in the Black Law Dictionary is "the complete relevance of all material facts". In order to conduct an initial public offering in the capital market, issuers have an obligation to disclose the information to the public in the form of submitting company conditions, one of which is from a legal perspective. Initial public offering (IPO) a company's first public sale of stock, offerrring an issuer equity securities to public through a registration statement. ${ }^{5}$ Information disclosure is not only in the context of IPO but also when a public company takes corporate action. Corporate action according to Francis Groven defined as "..corporate action occurs when chages are made to the capital structure of financial position of an issuer of a security that affect any of the securities it has issue. ${ }^{6}$

Legal information disclosure is then shared in the prospectus, which is one of the registration statement

\footnotetext{
${ }^{1}$ Marzuki Usman, Singgih Riphat, Syahrir Ika, Basic Knowledge of Capital Markets, Financial and Monetary Journal, Jakarta, 1997, p.13.

${ }^{2}$ Irsan Nasarudin, Indra Surya, Legal Aspects of the Indonesian Capital Market, Kencana Prenada Media Group, Jakarta, 2011, p.32-37.

${ }^{3}$ Ibid.

${ }^{4}$ Bryan A. Garner, 1999, Black's Law Dictionary, Seventh Edition, West Group, St. Paul, Minn. p. 774.

${ }^{5}$ Ibid, p. 1189

${ }^{6}$ Francis Groves, Corporate Actions-a Concise Guide : an Introduction to Securities Events, Harriman House, Ltd, Great Britian, $2008, \mathrm{p} .4$.
} 
documents submitted by the issuer to the Financial Services Authority. Information disclosure can be a consideration for investors in deciding their investment in the capital market. This is in line with by Randolph P. Beatty and Ivo Welch who stated that .."registration statements is designed to disclose all information necessary for a reasonable investor to make an invesment decision". ${ }^{1}$

Legal disclosure of the information is carried out by a legal consultant in a legal audit report and a legal opinion report. These reports are called Legal Due Diligence (LDD). Based on their functions and responsibilities, the legal consultant provide opinions in the IPO process based on applicable regulations related to the use of IPO proceeds and the potential risks faced by issuers, as stated by Randolph P. Beatty and Ivo Welch that "The legal councel advises the IPO issuers concerning disclosures required in the narrative sections of the registration statement based on regulation. These disclosures must include the management discussion and anlysis, uses of procceds, and risk factor section of the registration statement". ${ }^{2}$

Legal consultants in formulating LDD are obliged to act independently as regulated in Article 67 of Law Number 8 of 1995 on the Capital Market, that “... in conducting business activities in the Capital Market sector, Capital Market Supporting Professionals are required to provide an independent opinion or assessment". The principle of Legal Consultants is interesting to study more deeply when it is related to the substance of advocates in Law Number 18 of 2003 on Advocates. The Advocate Law has different regulations regarding Advocates in providing legal services. Article 1 point 2 of the Advocate Law explicitly states that an advocate takes legal action for the client's legal interests. This suggests that an advocate's actions must reflect the interests of the client.

\subsection{Formulation of the problem}

Based on this background, the following problem formulations are proposed: (1) The principally of the obligations of legal consultants as a capital market supporting profession in the preparation of independent legal due diligence; (2) Legal due diligence as an independent opinion of a legal consultant to provide legal protection for investors.

\subsection{Research Methods and Approach}

The two problem formulations were analyzed using the normative legal research method. It is a research method to identify legal concepts and principles to solve legal issues and at the same time provide a prescription of what should be done. ${ }^{3}$ For this legal research, primary and secondary legal materials are used as research sources.

Primary legal materials are legal sources that are authoritative in principle, meaning that they have the authority in terms of legislation, official records, or minutes for the making of legislation and judges' decisions. Meanwhile, secondary legal materials are in the form of all publications on the law which are not official documents. Publications on law include textbooks, legal dictionaries, legal journals, and commentaries on court decisions. ${ }^{4}$

The approaches used in this study were statute approach, conceptual approach, comparative approach, case approach and philosophical approach. ${ }^{5}$

\section{Analysis and Results}

\subsection{The principally of the Obligations of Legal Consultant's as a Capital Market Supporting Profession in the Preparation of Independent Legal Due Diligence.}

The objective of developing a capital market in a country is to create a sustainable and stable national economy. To achieve this objective, it requires activities in the financial services sector that are organized in an orderly, fair, transparent, accountable, sustainable, and stable manner. The services are also required to be able to protect the interests of consumers and society. It is stated in the preamble to Law Number 21 of 2011 on the Financial Services Authority, where one of the main objectives of capital market development is to protect the interests of consumers and society. This is in line with one of the duties and responsibilities of a legal consultant in the capital market, in which "to conduct an assessment and submit a legal opinion regarding the fulfillment of the requirements of an offering, transaction, or investment activity conducted in the financial services sector". 6

The orientation of legal protection to the interests of consumers and society in the capital market has compelled legal consultants as capital market supporting professionals to act independently in providing legal judgments and opinions. The definition of independent is an attitude that must be possessed by a legal consultant in carrying out legal due diligence, in the Black's Law Dictionary it is divided into 3 (three) definitions, first "No subject to the control or influence of another" means that no one controls or influences, the second "Not associated

\footnotetext{
${ }^{7}$ Randolph P. Beatty and Ivo Welch, Issuer Expenses and Legal Liability in Initial Public Offerings, The Journal of Law \& Economics, Vol.39, No.2, University of Chicago Press, 1996, p. 348.

${ }^{2}$ Ibid, p. 349

${ }_{3}^{3}$ Peter Mahmud Marzuki, 2005, Legal Research, Kencana Prenada Media Group, Jakarta, 2005, p. 141.

${ }^{4}$ Ibid.

${ }^{5}$ Ibid, p. 96-105

${ }^{6}$ Indra Safitri, Capital Market Legal Consultant Profession in the Era of the Financial Services Authority (OJK), Law \& Capital Market Journal, Volume V/6th Edition, Capital Market Legal Consultant Association (HKHPM), Juli - November 2013, p.8
} 
with another (of the larger) entity" which is more directed to the independent subsidiary, and the third "Not dependent or contingent on something else" which is oriented to contrast with a dependent person. ${ }^{1}$ From the definitions, it is clear that the meaning contained in the term of independent is first, not controlled or influenced by other parties, second, not related or has a relationship with other parties, and third, not dependent on other parties.

Along with this line, independent advice is defined by Black's Law Dictionary as “...councel that is impartial and not given to further the interest of the person giving it. ${ }^{2}$ This term means that an opinion can be said to be independent if it is impartial and has no interest in the party requesting that opinion. In the context of legal consultancy as a capital market supporting profession, this definition can be interpreted that in providing an independent opinion, the opinion given does not have an element of partiality (impartial) and the independent opinion givers have no interest in the party requesting or obtaining their opinion or judgment.

The definition of independent advice by the Black's Law Dictionary is very appropriate when it is related to the existence of a legal consultant as a capital market supporting profession. The principle of independence of a legal consultant as a capital market supporting profession can be interpreted as an independent attitude from a legal consultant that is not controlled or influenced, is not related to other entities, and is not dependent on other parties. Thus, an independent party will be able to provide an independent opinion because the opinion given does not have a partial element and an independent opinion giver has no interest in the party requesting or obtaining the independent opinion. An independent attitude also means that a legal consultant is not affiliated with any public company or issuer, meaning that he/she has no relationship with any public company or issuer through share ownership and there is no control or influence from any public company or issuer.

Apart from being independent, legal consultants are required to be professional in carrying out their profession. The professional attitude refers to the level of skill that legal consultants should have in carrying out their profession. The level of skill that a legal consultant should have is the ability to act carefully, thoroughly, and prudently. A careful, thorough, and prudent professional attitude is one that always questions, evaluates, and critically analyzes various facts, evidence, and information that are known, received, or obtained by legal consultants. And legal consultants are also obliged to demonstrate their integrity, which is by forthrightly and transparently disclosing the truth of information or material facts that they have obtained so that the information presented is not misleading. In practical terms, legal consultants in conducting LDD do not provide an untrue statement or misrepresent or omit material facts. All of these attitudes must be met by a legal consultant in providing assessments and/or opinions independently and professionally.

\subsection{Legal Due Diligence as an Independent Opinion of a Legal Consultant to Provide Legal Protection for Investors.}

Since legal consultants and service users, or in this case the issuers, have a legal relationship that based on a contractual relationship, it is very appropriate for this study to use the theory of legal protection based on agreements or contracts initiated by Moch. Isnaenai, as described that:

The law, in this case, contract law, either by the business actors or by the internal parties, tries to create protective shields from the impact of the waves of loss that are always lurking. The protective shield provided by law in the business world, according to its origin, can be divided into two types: external legal protection and internal legal protection. ${ }^{3}$

It is further explained that external legal protection, is legal protection created by the authorities through regulations in the form of statutory regulations. This external legal protection, in general, is a bulwark prepared by the legislators to ward off loss as well as injustice for market players.

In the capital market sector, there are several forms of external legal protection. A study on legal protection for investors conducted by Rafael La Porta et.al. found several forms of external legal protection created by the authorities to provide legal protection for investors or shareholders in the capital market, they are "to receive devidends on pro-rata terms, to vote for directors, to participate in shareholders meetings, to subscribe to new issues of securities on the same terms as the insiders, to sue directors or the majority for suspected expropriation, to call extraordinary shareholders meetings, etc. ${ }^{4}$

In contrast to external legal protection, Moch. Isnaeni provides an explanation related to internal legal protection that:

"....... is a safeguard for the interests of the parties which is built on the basis of agreement, to be stated in the formulation of contract clauses that they build together. It was further explained that by making an agreement, based on the principle of freedom of contract, the parties could agree on and build their own

\footnotetext{
${ }^{1}$ Bryan A. Garner, Op.Cit, p. 774.

${ }^{2}$ Ibid

${ }^{3}$ Moch. Isnaeni, A Diorama of Contract Law, Revka Media, Surabaya, 2017, p. 41.

${ }^{4}$ Rafael La Porta, Florencio Lopez-de-Silanes, Andrei Shleifer, Robert Vishny, Investor Protection ad Corporate Governance, Jurnal of Financial Economics, Elsevier, 2000, p. 6.
} 
safety net. This internal legal protection can be developed properly as long as both parties have a balanced bargaining position. If the bargaining position is balanced, then an agreement written to properly protect the interests of each contractor can ensure a fair contract". ${ }^{1}$

However, there are still things that need to be explored further regarding the legal relationship between capital market legal consultants and service users based on the theory of internal legal protection. Because essentially, in providing opinions or assessments legal consultants must be independent, so legal protection efforts are not solely for the interests of the parties or the contractor.

The principle of the contract or agreement is limited to the parties who hold the obligations and receive the benefits of a legally binding agreement. In essence, the agreement they made was only binding and valid for the two parties who enter into an agreement, this is a reflection of the principle of the privity of contract as one of the important principles in contract law. With the privity of contract, the agreement only binds the parties who make it so that third parties who are not contractors are not bound by it. ${ }^{2}$ Privity of contract, comes from the root word privity which is defined by the Black Law Dictionary as "..The connection or relationship between two parties, each having a legally recognized interest in the same subject matter (such as a transaction, proceeding, or piece of property); mutuality of interest. The term of privity of contract is described by John Gooley as follow: ".. what has been referred to as the "fundamental" principles of contract law; namely, privity of contract. Pursuant to this principle, only parties to a contract can enforce the contract. Persons who stand to gain a benefit from the contract, but are not parties to it, have no rights of enforcement". ${ }^{3}$

John Gooley's view on the privity of contract is different from the definition of the term in the Black Law Dictionary which defines that privity of contract is: " the relationship between the parties to a contract, allowing them to sue each other but preventing a third party from doing so. The requirement of privity has been relaxed under modern laws and doctrines of implied warranty and strict liability, which allow a third-party beneficiary or other foreseeable user to sue the seller of a defective product". 4

A similar view of the privity of contract was expressed by Lastuti Abubakar, who explained that the privity of contract is a principle of personality that emphasizes that the agreement made cannot harm third parties who are not bound by the agreement. Likewise, the third parties outside the agreement cannot claim a right in the agreement. The binding of the parties to the agreement is not merely what is expressly stated in the agreement, but everything that according to the principle of the agreement is required by propriety, custom and law. ${ }^{5}$

A comprehensive view regarding the privity of contract was made by Moch Isnaeni who explained that as a principle, the privity of contract is like the freedom of contract principle which does not apply absolutely, meaning that in certain situations there are exceptions to be made to avoid unfairness. The exceptions can be in the form of committing deviations, thus, the principle is sacrificed for the sake of maintaining justice as one of the objectives of the law. ${ }^{6}$ Furthermore, it was also explained that the posture of deviation from the privity of contract due to the emergence of a certain situation as a valid reason is a sign of the relativity of the principle. All of these are deemed appropriate and proper and must be enforced, in order to realize justice as one of the fundamental objectives of the law. However, if the principle of the privity of contract is absolute, it means that it must apply in any circumstances. ${ }^{7}$ From these two views, it can be seen that deviation from the privity of contract is very possible and is made to avoid injustice or to realize justice as one of the most basic objectives of law.

From the perspective of the principle of a contract, essentially every contract contains the principle of the privity of contract. However, this principle is not absolutely autonomous, meaning that the binding power stated in the contract is not only for the contractors but also takes into account the developing laws, habits, and appropriateness. It is said that in a contract, apart from an autonomous element in the form of the will of the parties, heteronomous elements are also present. According to Moch Isnaeni, the heteronomous elements exist in the regulations, customs, and propriety, which also have a binding power to the parties. So the binding power of a contract, apart from being determined by the autonomic element, is also strengthened by the binding power by the heteronomous elements. ${ }^{8}$

From the view expressed by Moch Isnaensi, in the context of a binding agreement between legal consultants and issuers or service users, even though it departs from the privity of contract, a personal tie to protect the interests of the contractors and has an autonomous principle, however, there is also a presence of heteronomous elements in the form of the regulations, custom, and propriety. Apart from these three heteronomous elements, the contract must also take into account the interests of consumers and society, in this case, the interests of investors or minority

\footnotetext{
${ }^{1}$ Moch Isnaeni, Op.Cit, p. 42

${ }^{2}$ Ibid, p. 68.

${ }^{3}$ John Gooley, et.al., Principle of Australian Contract Law, LexisNexis, Butterworth, Australia, 2015, p.880.

${ }^{4}$ Ibid.

${ }^{5}$ Lastuti Abubakar, Derivative Transactions in Indonesia, Legal Review of Derivative Trading on the Stock Exchange, Books Terrace \& Library, Bandung, 2009, p.73

${ }^{6}$ Moch Isnaeni, Op.Cit, p. 72

${ }^{7}$ Ibid, p. 75 .

${ }^{8}$ Ibid. p.250-225
} 
shareholders and independent shareholders in certain transactions.

This is in line with the duties and obligations of a legal consultant in providing an independent opinion or assessment. This independence contains heteronomous elements as stipulated in the laws and regulations, customs, and propriety that apply in the capital market. Thus, in order to avoid injustice, from a practical point of view, legal consultants in conducting legal due diligence have an obligation not to provide any untrue statement of a material fact or is otherwise false or misleading. This is in line with the duties and obligations of a legal consultant in providing an independent opinion or assessment. This independence contains heteronomous elements as stipulated in the laws and regulations, customs, and propriety that apply in the capital market. Thus, in order to avoid injustice, from a practical point of view, legal consultants in conducting legal due diligence have an obligation not to provide any misstatement of a material fact or is otherwise false or misleading.

From this thought, it can be surmised that the obligation of a legal consultant as a capital market supporting profession is to provide an independent opinion or assessment. It is based on the concept that an agreement is internal legal protection with the privity of contract but also limited by heteronomous elements in order to provide protection against investors, minority shareholders, and independent shareholders in accordance with company actions and transactions carried out by service users.

\section{Conclusion}

Based on the discussion in the previous section, it can be concluded that:

1. The principle of independence of a legal consultant as a capital market supporting profession is a professional attitude that must be possessed and manifested through an independent attitude. By independent attitude, it means that the legal consultant is not under the control or influence of service users, is not affiliated with service users, do not have a conflict of interest with service users or the transactions being carried out, and do not have an element of partiality with the service users.

2. The legal relationship between the legal consultant and service users is bound by an agreement, thus the parties have built their respective internal legal protections. Although this legal relationship can be categorized as an internal legal protection effort based on the privity of contract, a contract is not absolutely autonomous because it must also pay attention to regulations, customs, and propriety or are called heteronomous elements. Taking heteronomous elements into account in the capital market is a legal obligation to provide protection to investors, minority shareholders, and independent shareholders.

\section{Reference}

Books

Abubakar, Lastuti, 2009, Derivative Transactions in Indonesia, Legal Review of Derivative Trading on the Stock Exchange, Books Terrace \& Library, Bandung.

Beatty,Randolph P. and Ivo Welch, 1996, Issuer Expenses and Legal Liability in Initial Public Offerings, The Journal of Law \& Economics, Vol.39, No.2, University of Chicago Press.

Garner, Bryan A., 1999, Black's Law Dictionary, Seventh Edition, West Group, St. Paul, Minn.

Gooley, John, et.al., 2015, Principle of Australian Contract Law, LexisNexis Butterworth, Australia.

Groves, Francis, 2008, Corporate Actions-a Concise Guide: an Introduction to Securities Events, Harriman House, Ltd, Great Britian.

Isnaeni, Moch., 2017, A Diorama of Contract Law, Revka Media, Surabaya.

La Porta, Rafael, Florencio Lopez-de-Silanes, Andrei Shleifer, Robert Vishny, 2000, Investor Protection ad Corporate Governance, Jurnal of Financial Economics, Elsevier.

Marzuki, Peter Mahmud, 2005, Legal Research, Kencana Prenada Media Group, Jakarta.

Nasarudin, Irsan, Indra Surya, 2011, Legal Aspects of the Indonesian Capital Market, Kencana Prenada Media Group, Jakarta.

Safitri, Indra, 2013, Capital Market Legal Consultant Profession in the Era of the Financial Services Authority $(O J K)$, Law \& Capital Market Journal, Volume V/6th Edition, Capital Market Legal Consultant Association (HKHPM).

Usman, Marzuki, Singgih Riphat, Syahrir Ika, 1997, Basic Knowledge of Capital Markets, Financial and Monetary Journal, Jakarta.

\section{Legislation}

Law Number 21 of 2011 on the Financial Services Authority.

Law Number 8 of 1995 on Capital Market.

Law Number 18 of 2003, on Advocates. 